\title{
SILICEOUS MICROFOSSILS
}
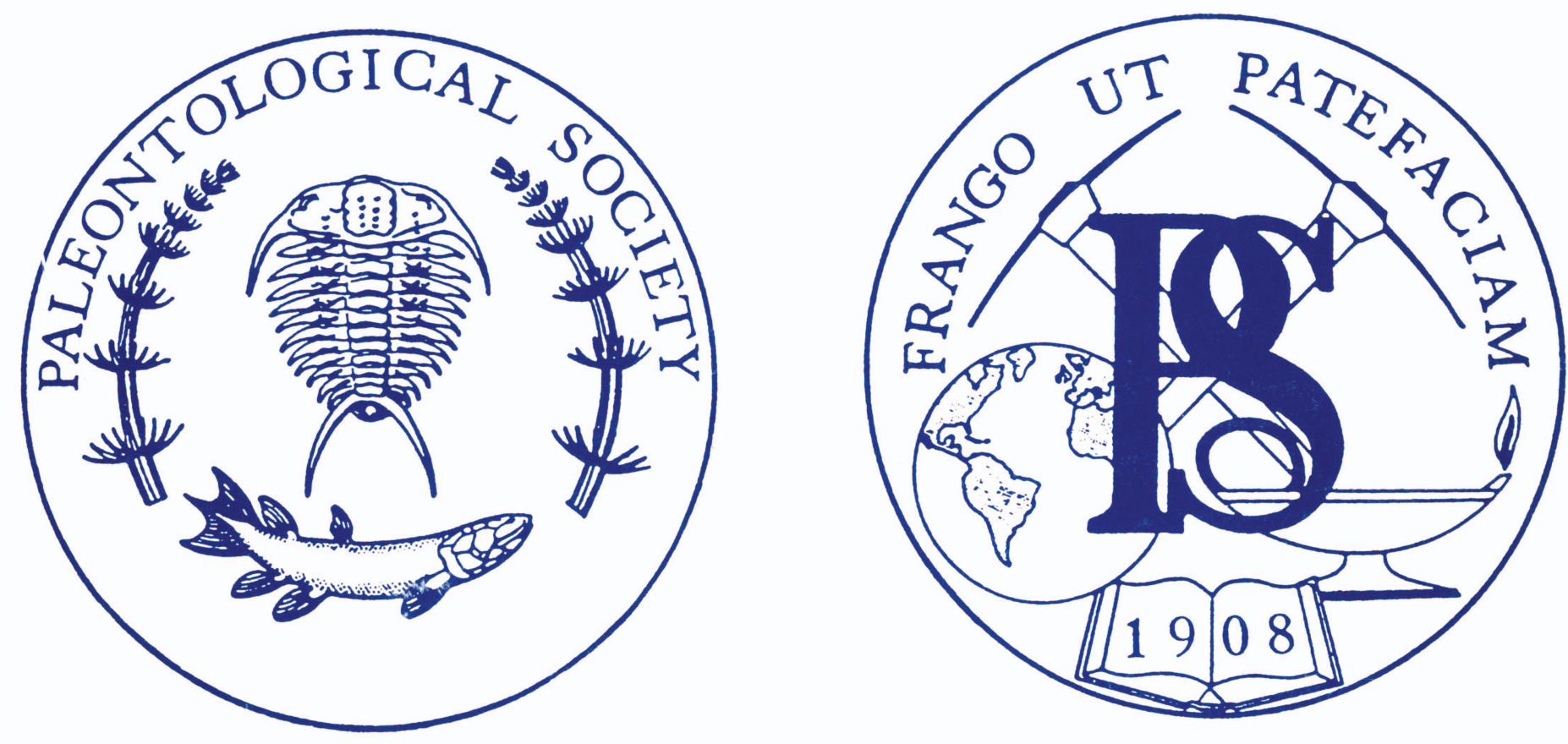

SHORT COURSES IN PALEONTOLOGY

NUMBER 8

1995

convened by Charles D. Blome, Patricia M. Whalen, and Katherine M. Reed

Loren E. Babcock and William I. Ausich, Series Editors

A Publication of The Paleontological Society 
UTK Publication FO1-1040-004-96

The University of Tennessee, Knoxville, does not discriminate on the basis of race, sex, color, religion, national origin, age, handicap or veteran status in provision of educational opportunities or employment benefits.

UTK does not discriminate on the basis of sex or handicap in the educational programs and activities which it operates, pursuant to requirements of Title IX of the Educational Amendments of 1972, Public Law 92-318; and section 504 of the Rehabilitation Act of 1973, Public Law 93-112; respectively. This policy extends both to employment and admission to the University.

Inquiries concerning Title IX and Section 504 should be directed to the Director of Affirmative Action; 403-B Andy Holt Tower; The University of Tennessee, Knoxville, Tennessee 37996-0144; (615) 974-2498. Charges of violation of the above policy should be directed to the Office of the Director of Affirmative Action. 


\section{SILICEOUS MICROFOSSILS}
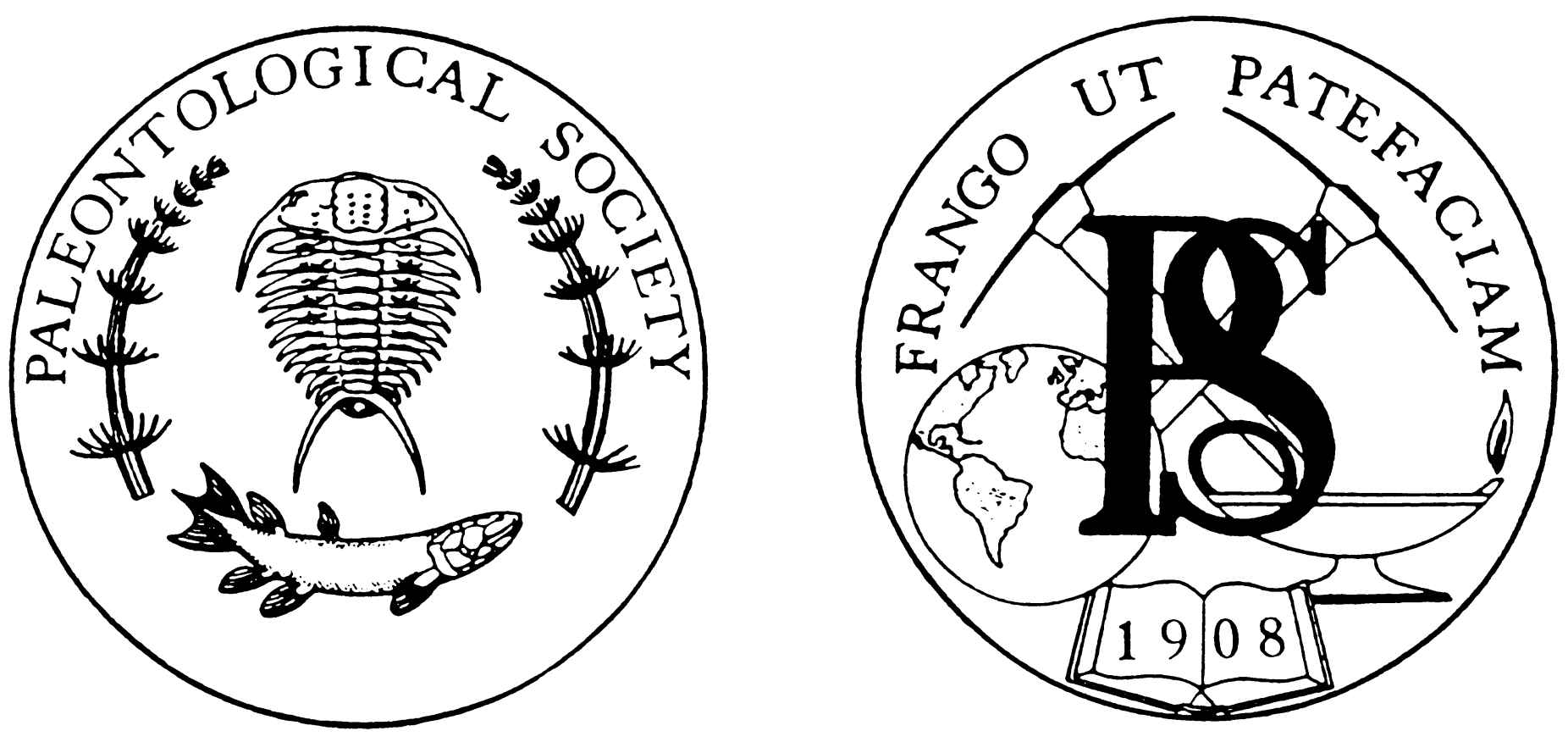

SHORT COURSES IN PALEONTOLOGY

NUMBER 8

1995

convened by Charles D. Blome, Patricia M. Whalen, and Katherine M. Reed

Loren E. Babcock and William I. Ausich, Series Editors

A Publication of The Paleontological Society 


\section{CONTENTS}

ii PROGRAM

iii PREFACE

iv AUTHORS

1 Sponges as Microfossils

by J. Keith Rigby

19 Status of Ordovician and Silurian Radiolarian Studies in North America

by P. J. Noble and J. C. Aitchison

31 Mesozoic Radiolaria

by Charles D. Blome, Donna Meyerhoff Hull, Emile A. Pessagno, Jr., and K. M. Reed

61 Cenozoic Radiolaria

by Annika Sanfilippo

81 Cretaceous Diatoms: Morphology, Taxonomy, Biostratigraphy

by David M. Harwood and Vladimir A. Nikolaev

107 Cenozoic Marine Diatom Biostratigraphy and Applications to Paleoclimatology and Paleoceanography

by John A. Barron and Jack G. Baldauf

119 Fossil Continental Diatoms: Paleolimnology, Evolution, and Biochronology

by J. P. Bradbury and W. N. Krebs

139 Siliceous Chrysophycean Microfossils: Recent Advances and Applications to Paleoenvironmental Investigations

by Katharine E. Duff and Barbara A. Zeeb

159 Silicoflagellates

by Kevin McCartney

177 Ebridians and Endoskeletal Dinoflagellates

by John J. Ernissee and Kevin McCartney 